\title{
Symmetrical infantile thalamic degeneration in two sibs
}

\author{
DIANNE N ABUELO, GAIL BARSEL-BOWERS, BARBARA G TUTSCHKA, \\ MARY AMBLER, AND DON B SINGER
}

From the Departments of Pediatrics and Pathology, Rhode Island Hospital and Women and Infants Hospital, Brown University School of Medicine, and the Genetic Counseling Center, Rhode Island Hospital, USA

SUMMARY This is the first observation of two cases of symmetrical infantile thalamic degeneration with cell mineralisation in a family. Although it cannot be established at present, autosomal recessive inheritance of a metabolic error causing or predisposing to damage to specific areas of the central nervous system is a possible aetiology for this condition.

Symmetrical infantile thalamic degeneration with mineralisation is an extremely rare condition, the aetiology of which is unknown. Birth injury and toxic or infectious agents are speculative causes. ${ }^{12}$ The disorder, which is associated with severe neurological impairment and early death, occurs sporadically and has not been reported to have an appreciable risk of recurrence for the parents of an affected infant.

We wish to report the occurrence of symmetrical infantile thalamic degeneration in two sibs born to unrelated parents after uncomplicated pregnancies and deliveries. An autosomal recessive mode of inheritance may be responsible.

\section{Case reports}

CASE 1

This case, born 2.10 .73 and described in 1975 by Ambler and O'Neil, ${ }^{2}$ was a $3380 \mathrm{~g}$ male. He was born after a normal term pregnancy and delivery to a 23-year-old primigravida of French Canadian ancestry and 24-year-old father of Portuguese ancestry. The infant did not breathe spontaneously for one minute and was given positive pressure oxygen. Two hours after birth, marked spasticity of both upper extemities and opisthotonic posturing developed. Because of poor suck reflex, gavage feedings were required. The cry was high-pitched. Periods of apnoea and bradycardia developed and became more frequent and prolonged. Laboratory studies, including amino-acids and mucopolysaccharide screening tests, were negative. Despite intensive supportive measures, the infant died at Received for publication 3 January 1981
3 weeks of age of cardiorespiratory arrest. Necropsy showed no gross anomalies. Microscopical examination of the thalamic and hypothalamic nuclei showed severe cell loss, mineralisation, and astrogliosis without necrosis or inflammation. Electron microscopy revealed unusual cytoplasmic inclusion with material thought to be calcium. The cells involved could not be specifically identified. A more detailed pathological description can be found in the publication of Ambler and O'Neil. ${ }^{2}$

The family was told that the condition was not known to be a genetic one, and was not likely to recur. They subsequently had two normal boys.

CASE 2

The sister of case 1 was born 7.11.78. The pregnancy was uncomplicated and delivery was normal. Birthweight was $2670 \mathrm{~g}$ and Apgar scores were 2 and 8 at 1 and 5 minutes, respectively. One hour after birth, the infant developed rigidity with flexion of the arms against the chest and scissoring of the legs. Muscle tone increased more in the upper than in the lower extremities. She developed episodes of apnoea and bradycardia at 10 days of age. Electroencephalogram was repeatedly abnormal. Skull $x$-rays and CT scan showed no abnormalities. Urine screening tests for amino-acids, organic acids, and mucopolysaccharides were negative. Copper metabolism was not studied. The episodes of apnoea and bradycardia became more severe and were complicated by cyanosis and seizure activity. At the request of the family, the infant was discharged home with an apnoea monitor. She died at 2 months of age.

Necropsy was restricted to examination of the central nervous system. The brain had microgyria 
and weighed $330 \mathrm{~g}$ (the expected normal weight is $442 \mathrm{~g}$ ). Microscopically, major neuronal loss and gliosis involved the thalamus, medial globus palladus, mamillary bodies, and dentate nucleus and occurred throughout the cerebral white matter. Neurones of the hippocampus and cerebellar cortex were markedly preserved. Gliosis of hemispheric white matter was prominent. Mineral concretions were noted only in cells of the thalamus (fig 1). The

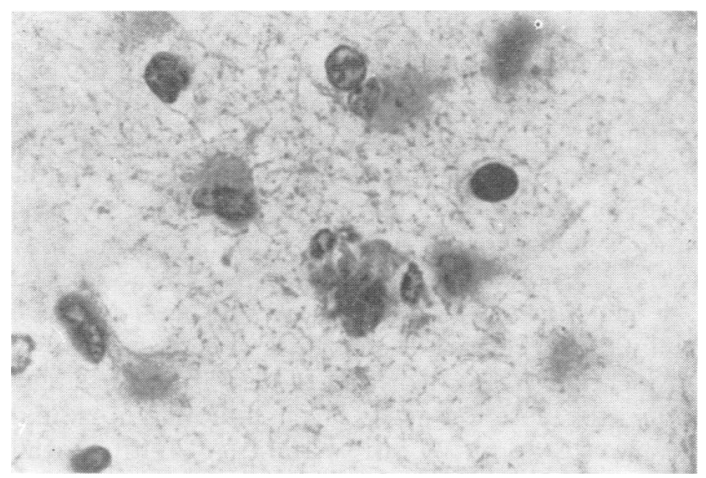

FIG 1 Cells in the basal ganglia of case 2 showsd degenerative change, predominantly in the cytoplasm. Particulate debris, negative for calcium and for iron, obscured nuclear and cytoplasmic detail. Glial cells were noted at the edge of the damaged cell. (Haematoxylin and eosin. Original magnification $\times 930)$.

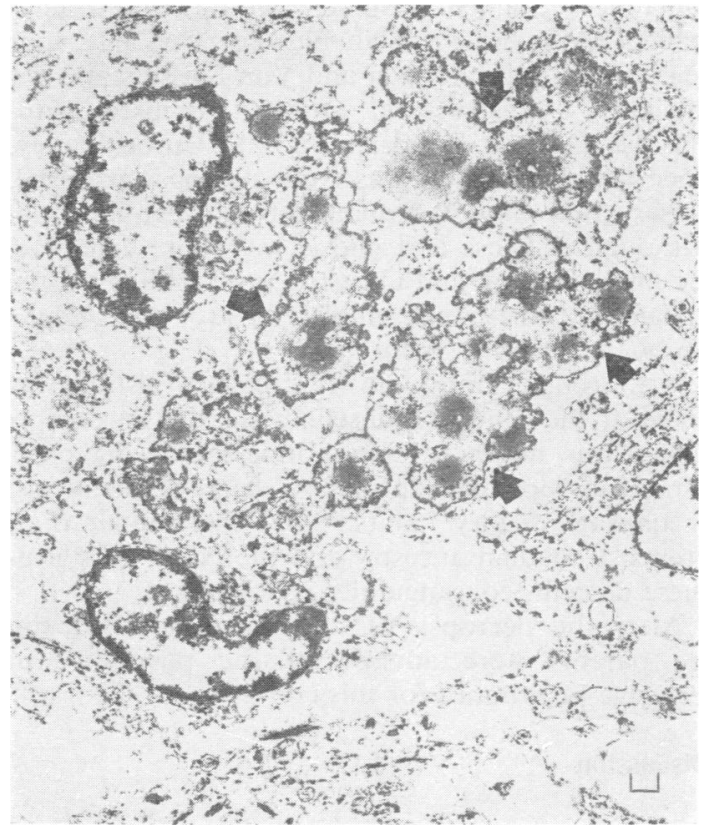

FIG 2 Ultrastructure of the formalin fixed brain from case 2 shows a cytoplasmic remnant (arrows) of an unidentified cell surrounded by a membrane and containing irregular dense globular deposits. Bracket indicates 1 micrometer.

TABLE Summary of all cases

\begin{tabular}{|c|c|c|c|c|c|c|c|}
\hline Case No & $\begin{array}{l}\text { Gestational } \\
\text { age }\end{array}$ & $\begin{array}{l}\text { Labour and } \\
\text { delivery }\end{array}$ & Birthweight & Apgars & $\begin{array}{l}\text { Clinical } \\
\text { features }\end{array}$ & $\begin{array}{l}\text { Age at } \\
\text { death }\end{array}$ & Pathological features \\
\hline Our case 1 & Term & Normal & $3380 \mathrm{~g}$ & $\begin{array}{l}\text { 1st breath } \\
\text { at } 1 \mathrm{~min}\end{array}$ & $\begin{array}{l}\text { Spasticity, } \\
\text { opisthotonus, } \\
\text { apnoea }\end{array}$ & 3 wk & $\begin{array}{l}\text { Thalamic and hypothalamic cell } \\
\text { loss, astrogliosis with cytoplasmic } \\
\text { inclusions }\end{array}$ \\
\hline Our case 2 & Term & Normal & $2670 \mathrm{~g}$ & $2^{1}, 8^{5}$ & $\begin{array}{r}\text { Spasticity, } \\
\text { apnoea, } \\
\text { seizures }\end{array}$ & $2 \mathrm{mth}$ & $\begin{array}{l}\text { Cell loss and gliosis in thalamus } \\
\text { and white matter, mineral } \\
\text { concretions in thalamus }\end{array}$ \\
\hline \multicolumn{8}{|l|}{$\begin{array}{l}\text { Cases of } \\
\text { Norman }^{3}\end{array}$} \\
\hline 3 & Term & $\begin{array}{r}\text { Footling } \\
\text { breech }\end{array}$ & $2730 \mathrm{~g}$ & 1 & $\begin{array}{l}\text { Hypertonicity, } \\
\text { opisthotonus, } \\
\text { apnoea }\end{array}$ & $43 \mathrm{dy}$ & $\begin{array}{l}\text { Neuronal loss and encrustation } \\
\text { of the thalamus with } \\
\text { hypertrophied astrocytes }\end{array}$ \\
\hline 4 & 34 weeks & Breech & $1950 \mathrm{~g}$ & 1 & $\begin{array}{l}\text { Flaccid, } \\
\text { arreflexic } \\
\text { episodes of } \\
\text { stiffness }\end{array}$ & $1 \mathrm{wk}$ & $\begin{array}{l}\text { Neuronal loss and hypertrophied } \\
\text { astrocytes in thalamus and } \\
\text { reticular formation }\end{array}$ \\
\hline 5 & 34 weeks & $\begin{array}{l}\text { Fetal } \\
\text { distress }\end{array}$ & $1960 \mathrm{~g}$ & 2 & Flaccid & $8 \mathrm{dy}$ & $\begin{array}{l}\text { Neuronal loss, encrusted neurones, } \\
\text { increased glia in thalamus and } \\
\text { reticular formation }\end{array}$ \\
\hline \multicolumn{8}{|l|}{$\begin{array}{l}\text { Cases of } \\
\text { Rosales } \\
\text { and Riggs1 }\end{array}$} \\
\hline 6 & Term & Spontaneous & & $\begin{array}{l}10 \text { mins of } \\
\text { apnoea }\end{array}$ & $\begin{array}{l}\text { Spastic } \\
\text { paraplegia } \\
\text { from birth }\end{array}$ & $6 \mathrm{mth}$ & \\
\hline 7 & Term & Spontaneous & $\begin{array}{l}\text { Between } \\
2550 \text { and } \\
3399 \mathrm{~g}\end{array}$ & $\begin{array}{l}\text { Breathed } \\
\text { and cried } \\
\text { immediately }\end{array}$ & $\begin{array}{l}\text { Spasticity, } \\
\text { seizures, } \\
\text { apnoea }\end{array}$ & $15 \mathrm{mth}$ & $\begin{array}{l}\text { Parenchymous atrophy of thalamus } \\
\text { with astroglial hyperplasia with } \\
\text { abnormal structures resembling } \\
\text { fossilised neurones }\end{array}$ \\
\hline 8 & Term & Spontaneous & & $?$ & Opisthotonus & $16 \mathrm{mth}$ & \\
\hline
\end{tabular}


concretions stained positively with periodic acidSchiff (PAS) and prussian blue for iron but were negative with alizarin red and Von Kossa stains for calcium. Ultrastructural studies disclosed cytoplasmic globular deposits (fig 2). Unfortunately, since the preparation was from necropsy material, preservation was inadequate for cell identification. Although cell loss and gliosis was more extensive, the microscopical and ultrastructural findings in the thalamus of this case resembled those of the patient's sib but were more severe.

A thorough family and toxicological history was taken at the genetic counselling clinic. The parents denied any major or minor illnesses during pregnancy, any possible exposure to drugs or chemicals, or unusual dietary habits. Since the mother is of French Canadian ancestry and the father of Portuguese descent, consanguinity is unlikely.

After the necropsy of the second affected sib, the parents were advised of the possibility of recessive inheritance for this condition.

\section{Discussion}

Loss of cells with associated mineralisation of cellular remnants occurs in the brains of newborn infants with two recognised patterns. The brains of neonates who suffer severe intrauterine asphyxia, perinatal asphyxia, or other perinatal injury often have loss of cells in a diffuse pattern of distribution and cellular remnants may be mineralised. ${ }^{3}$ On the other hand, symmetrical infantile thalamic degeneration, in which cell loss, damage, and mineralisation of cells is limited to the thalamus, is a rare condition. ${ }^{12}$ The aetiology and pathogenesis of the latter condition are poorly understood.

We report two sibs, one with lesions restricted to the thalamus, the other with thalamic lesions and a wider distribution of damaged cells. Both had cellular mineral deposits. In both sibs, the antenatal events were considered normal yet each infant had $\Omega$

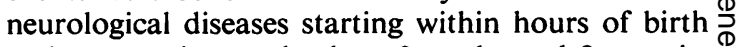
and progressing to death at 3 weeks and 2 months ? of age, respectively. There were no dysmorphic $\overrightarrow{\vec{F}}$ external physical features. Both patients and those $\vec{\sigma}$ reported by Rosales and Riggs ${ }^{1}$ had spasticity, an $\frac{\mathrm{C}}{0}$ unusual finding in the first weeks of life. Other $\frac{\bar{c}}{\omega}$ clinical features were similar: low Apgar scores, $\vec{\nabla}$ poor or absent suck reflex, and later development of $\propto$ apnoea and seizures. (See the table for summary of information of all cases reported to date.)

While the clinical courses in the two sibs were similar, the distribution of lesions in the brain was $\vec{\omega}$ more widespread in the second infant. This may be? attributed to the longer survival, 2 months as, opposed to 3 weeks, allowing more time for addi- $\dot{\infty}$ tional or secondary lesions to develop. Anoxic $\stackrel{\infty}{\sigma}$ episodes and seizures in the perinatal period may have contributed to the dispersion of the lesions.

A genetic aetiology for symmetrical infantile 은 thalamic degeneration has not been previously considered. With two affected sibs in a single family, the aetiology may be a mutant autosomal $\varnothing_{\varnothing}^{\infty}$ recessive gene in both parents. Multifactorial $\frac{\pi}{3}$ inheritance and environmental teratogens must also be considered.

\section{References}

1 Rosales RK, Riggs HE. Symmetrical thalamic degener? tion in infants. J Neuropathol Exp Neurol 1962;21:372-6.

2 Ambler M, O'Neil W. Symmetrical infantile thalamic degeneration with focal cytoplasmic calcification. Acta $\frac{\text { D }}{8}$ Neuropathol 1975;33:1-7.

3 Norman MG. Antenatal neuronal loss and gliosis of the $\overrightarrow{\vec{A}}$ reticular formation, thalamus, and hypothalamus. Neurology (Minneap) 1972:22:910-6.

Requests for reprints to Dr D N Abuelo, Genetic Counseling Center, Rhode Island Hospital, 593 Eddy Street, Providence, Rhode Island 02902, USA. 